\title{
THE EFFECT OF INSTITUTIONAL CONTEXT ON THE GOVERNANCE OF EMERGENT SUPPLY CHAINS: A CASE STUDY OF CASSAVA SECTOR IN VIETNAM
}

\author{
Kien Trung Nguyen* \\ Institute of Policy and Strategy for Agriculture and Rural Development, Vietnam \\ *Corresponding author: kien.nt@ipsard.gov.vn
}

\begin{abstract}
This paper investigates how transactions between firms are organized in an emerging market and how supply network governance affect supply network outcomes and catching up of merging market firms. We explored firms' choices of governance in a specific context of Vietnam, where legal institution is characterized by a weak legal system for contractual enforcement and socio-economic institution is characterized by transition from central planning into market mechanism. This study examines how firms in the cassava sector in Vietnam structure their transactions and how supply network governance relates to certain supply network outcomes. A comparative case study method was adopted in this research. Two cassava supply networks, of which one is traditional type and another is led by a foreign invested firm, were selected for study. Our findings indicate that institutional context, supply chain structure, product characteristic, relationship investment influence on firms' choices of governance and firms' choices of governance affect supply chain network outcomes and local firms' catching up. In the absence of legal enforcement, market governance is popularly applied in the supply chain with fragmented structure while relational governance is a popular used in more concentrated supply network. Higher value creation and more possibilities for catching up but more inequality in income distribution in supply chain with large scale lead firm. Lower value creation, rare possibilities for catching up but more equality in income distribution in supply chain with fragmented small scale firms.
\end{abstract}

Keywords: cassava supply chain, inter-firm governance, economic transactions, contract enforcement, institutional environment

Abstrak: Kajian ini menyelidiki tentang bagaimana transaksi antar perusahaan
diorganisasikan dalam sebuah pasar yang sedang berkembang, serta bagaimana tata
kelola jaringan pasokan mempengaruhi hasil jaringan pasokan dan mengejar
ketertinggalan dari penggabungan pasar perusahaan. Kajian ini mengeksplorasi pilihan
tata kelola perusahaan dalam konteks spesifik Vietnam, di mana lembaga hukum
dicirikan oleh sistem hukum yang lemah untuk penegakan kontrak dan lembaga
sosial-ekonomi ditandai oleh transisi dari perencanaan pusat ke mekanisme pasar.
Kajian ini untuk mengetahui bagaimana perusahaan sektor singkong di Vietnam
menyusun transaksi dan bagaimana tata kelola jaringan pasokan memengaruhi hasil
jaringan pasokan yang ada. Kajian ini menggunakan metode studi komparasi kasus.
Dua jaringan singkong, tipe tradisional dan perusahaan investasi asing dipilih dalam
penelitian ini. Hasil kajian menunjukkan bahwa konteks kelembagaan, struktur rantai
pasokan, karakteristik produk, pengaruh investasi pada pilihan tata kelola perusahaan
dan pilihan tersebut memengaruhi hasil jaringan rantai pasokan dan mengejar
ketertinggalan perusahaan. Tidak adanya penegakan hukum dalam membuat tata
kelola pasar secara populer diterapkan dalam rantai pasokan dengan struktur
terfragmentasi, sedangkan tata kelola relasional pada umumnya digunakan dalam
jaringan pasokan yang lebih terkonsentrasi. Penciptaan nilai yang lebih tinggi dan 


\section{Kien Trung Nguyen : The Effect Of Institutional Context On The Governance ...}

lebih banyak kemungkinan untuk mengejar ketinggalan, namun lebih banyak ketimpangan dalam distribusi pendapatan dalam rantai pasokan dengan perusahaan pemimpin berskala besar. Penciptaan nilai yang lebih rendah jarang memiliki kemungkinan untuk mengejar ketertinggalan, namun distribusi pendapatannya lebih merata dalam rantai pasokan dengan perusahaan skala kecil yang terfragmentasi.

Kata kunci: rantai pasok singkong, tata kelola antar perusahaan, transaksi ekonomi, penegakan kontrak, lingkungan kelembagaan

\section{INTRODUCTION}

A large body of research in supply chain management has investigated the linkage between a supplier and a buyer mostly from transaction cost economics and industrial network perspective and overlooked the role of institutional environments in which companies work with their suppliers (Wathne and Heide, 2004). Transaction cost economics was originated from institutional contexts with a long tradition of contract laws and strong legal regimes. It takes time to develop such strong legal institutions in the emerging markets which have experienced massive changes in economic, social, and political institutions. When strong legal institutions are absent, informal institutions based on personal connections and social network play a pivotal role. Studies of transition economies from institutional perspective (McMillan and Woodruff, 2002) found that firms in these economies employed relational governance which is coordinated by private ordering mechanisms such as trust and reputation to safe guard against limited roles of courts for transactional assurance. However, while relating the legal institution and firms' choices of mechanism to govern economic transactions in emerging market, these studies have ignored other aspects of inter-firm relationships such as transaction characteristics, the industrial structure and production-process characteristics. As a result, explanations of firms' choices of mechanism to govern supply network in emerging market by extant literatures are inadequate. Additionally, since personal relationships are difficult to build and costly to maintain, reliance on personal connections and social network to govern economics transaction may not be able to catch up with rapid growing exchange scale in emerging markets. So how could companies manage their relationships with suppliers in emerging markets? No adequate answer has been provided in extant literature while in practice a growing number of firms have involved in sourcing from emerging markets.

This paper aims to address this gap by taking Vietnam as an empirical setting for a study of firms' choice of supply network governance. Vietnam offers a good context for the study. Since the country's membership to WTO in 2007, Vietnam has established itself as a global production base for consumer products like garment, footwear, furniture and home accessories. Despite a lot of optimism about the benefits of sourcing from this market, Vietnam's institutional context has been posing a number of challenges for supply chain management. Transforming from a centrallyplanned economy to a market-oriented system in the late 1980s, the economic and legal institutions in Vietnam still functions imperfectly despite the government's efforts in reforming legal systems. The agriculture sector, specifically cassava supply chains in Vietnam, is selected for the studying order to timely provide managerial implications for supply chain management in this sector. Vietnam has emerged as a global production base for not only industrial products but also agriculture products. A number of global agro-food processing companies such as Nestle, Unilever, Vedan as well as supermarket chains like Carrefour, Tesco and Wal-Mart came to this country to source for agro-products. Unlike industrial sector in which production has been modernized, agriculture sector in Vietnam is characterized by small scaled and fragmented production without advanced farming technology. These potentially create significant challenges for managing agro-food supply networks in Vietnam.

This study examines how firms in the cassava sector in Vietnam structure their transactions and how supply network governance relates to certain supply network 
outcomes. A comparative case study method was adopted in this research. Two cassava supply networks, of which one is traditional type and another is led by a foreign invested firm, were selected for study.

The remainder of the article is organized as follows: The next section provides a review of the key literature underpinning research on supply chain relationship management, followed by the research methodology. Later, the findings of the study are illustrated before a discussion and conclusion.

\section{THEORETICAL BACKGROUNDS}

Supply networks are characterized by sets of connected exchange relationships in the performance of production tasks (Andersen and Christensen, 2005). An understanding of how firms organize, coordinate and monitor the connected exchange relationships and how the systems of coordination, organization and control relate to certain outcomes of supply networks is a key issue for practitioners and scholars alike. To investigate this issue, we employ the concept of governance given by Jessop (1998) and define supply network governance as systems of coordination, organization and control transactions between supply network partners. Early research on supply chain governance focused on dyadic relationship between buyers and suppliers but later on research shifts a focus from dyads to networks (Pilbeam et al., 2012).

Transaction Cost Economics (TCE) has been key theoretical perspectives underpinning research on dyad transaction between buyers and suppliers. According to TCE (Williamson, 1975; 1979; 1991, 1996), a firm makes a choice of governance mechanism upon the nature and level of transaction costs which are determined by the degree of uncertainty, asset specificity and frequency of the transaction. Williamson (1991) view governance structure as a continuum. At one extreme lies spot markets, where transactions are solely determined by prices, while, at the other end lies full vertical integration, where all transactions are carried out under one ownership. In between these two extremes lie various hybrid forms of governing economy activities, such as contracts, strategic alliances, joint ventures, etc. Peterson et al. (2001) specify TCE's governance structure into five major mechanisms namely spot/cash markets, specification contracts, relation-based alliances, equity-based alliances, and vertical integration.

Contract is an important instrument in inter-firm governance. Williamson (1996) proposes a schema which matches a governance mechanism with relevant type of contract. Market governance with classical contracting for non-specific transactions happens in the spot market where demand and supply are determined by prices. Contractual transaction is defined as the occasional transactions conducted under written agreement between buyers and sellers. TCE has been criticized for the two major following shortcomings. First, TCE does not take into account the effects of trust and other forms of social embeddedness (Gulati, 1995). Second, the vertical integration is not the only way of resolving the contractual hazards associated with asset specificity.

The industrial networks perspective addresses these two shortcomings by emphasizing on different aspects of inter-firm relationships: prior to transactions, i.e. the history of transactions and the social context under which transactions are embedded (Granovetter,1985; Thorelli, 1986; Lorenz, 1988; Jones et al., 1997). They defined relational governance as 'inter-firm coordination which is characterized by organic or informal social systems'. Trust and reputation is a key instrument of the relational governance. They are regarded as means to enhance transaction outcome with less monitoring and bargaining. However, trust and reputation are not enough to safeguard economic transactions, especially in a market characterized by high volatility and rapid technological changes. The Network Theory omits the internal logics of sectors, such as industrial structure and production-process characteristics when studying the choice of governance (Bair, 2005).

Evolved from TCE and Network theory, GVCs approach overcomes the shortcomings previous theories by developing a theoretical model with five governance mechanisms which are determined by three factors of transaction characteristics: (i) The complexity of transactions, i.e. the complexity of information and knowledge transfer required to maintain a 
specific transaction; (ii)The codifiability of transactions, (iii) the capabilities of suppliers required to a specific transaction (Gereffiet al., 2005). Based on the level of coordination and control among supply network actors, GVCs introduce three new types of governance namely modular linkages, relational linkages, and captive linkages. In fact, this distinction does not introduce new types of mechanism which firms used to govern transactions with supply network partners. At nutshell, modular and captive linkages belong to contractual governance introduced by TCE. Combining these three literature schools, we will investigate four main types of governance mechanism: spot market, contractual, relational and hierarchy. The different between contractual governance and relational governance is which instruments formal like contract or informal like social norm like trust is mainly used to coordinate transactions.

Gereffi et al. (2005) contribute to literature by specifying TCE's concept of transaction cost to a 'mundane transaction costs' which refers to the cost of monitoring and enforcement in outsourcing relationships. However, due to mainly focusing on mundane transaction costs to explain for firm's choice of governance, GVCs discussion of governance is neglecting the importance of the institutional environment under which transactions are embedded (Levy, 2005: 15).Gereffiet al. (2005: 99) believe that: "the variables internal to our model influence the shape and governance of global supply chains in important ways, regardless of the institutional context within which they are situated'.

Institutional environment refers to 'the set of fundamental political, social and legal ground rules that establishes the basis for production, exchange, and distribution' (Davis and North, 1971: 6). Institutional environment thus is related to macrostructure such as politics, law, the judiciary, norms and customs. Institutional environment differs between countries and even within a country. Recent studies in developing and transitional economies have found that institutional environment such as politics, law, the judiciary, norms and customs have influenced costs of governance and hence, the choices between alternative governance patterns (North, 1990; Johnson and Loveman,1995; Johnson et al.,1997; McMillan and Woodruff, 1999; Johnson et al., 2002). Therefore, institutional environment should be incorporated in a study of firm's choice of supply chain governance in emerging market.

In a review of literature on supply chain governance, Pilbeam et al. (2012) indicated a number of gaps in existing empirical knowledge of the institutional contexts and outcomes of supply network governance. In order to summarize the issues relating to supply network governance studied in extant literature, Pilbeam et al. (2012) developed an analytic framework which suggest that the instruments of supply network governance (I) may produce different supply network outcomes $(\mathrm{O})$ based on different mechanisms (M) depending upon the specific supply network context (C).

\begin{tabular}{||l||}
\hline Context: \\
Environment \\
Globalization, \\
Changing organization, \\
Uncertainty, \\
Unpredictability, Risk, \\
Legislation \\
Feature of actors \\
Relationship history, \\
Partner characters \\
\\
\hline
\end{tabular}
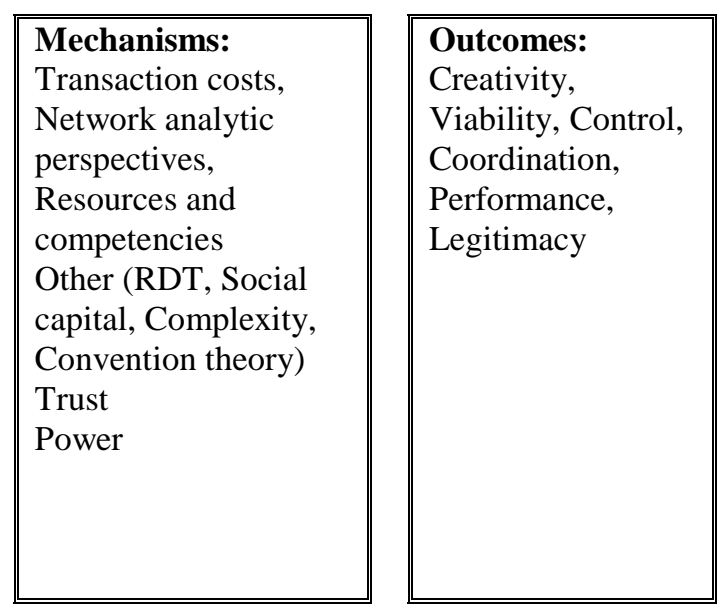

Source: Pilbeam et al. (2012), p:359

Figure 1. Context, Governance Instruments, Mechanism and Outcome 
They summarized the factors studied in the extant literature on supply chain governance which are presented in Figure 1.

Adopting this CIMO-logic and combined with the theories review above, we develop our analytical framework which includes four categories: (i) Context with a focus on some concepts like institutional context and feature of supply chain structure(ii) Instruments with a focus on some concepts like standard, process, contract, trust and information sharing (iii) Mechanisms with focus some concepts like spot market governance, contractual governance, relational governance and hierarchy; (iv) Outcome with focus on performance in term of profitability. We will use this analytical framework as a guide to explore how firms in emerging market structure and govern transactions with their supply chain network partners and how these relate to supply chain outcomes.

\section{RESEARCH METHODS}

This paper employs a case study strategy because of its advantages and relevance to our "How" research questions (Yin, 2009). The paper takes transaction relation as the unit of analysis. We collected data from in-depth interviews (semi-structured interviews) and secondary sources. In-depth interviews were conducted with various participants in the upstream of the two supply chains. Two sampling methods were employed: snowball and typical case sampling (Patton, 1990). The snowball sampling was first employed to select a sample of participants in different tiers in each supply chain. It is difficult to locate actors who participate in these supply chains. Therefore, we first conducted in-depth interviews with a focal firm in each of these supply chains. These firms then were asked to provide a list of their current first-tier suppliers (in the case of a trading facilitator, a list of his buyers was also inquired). From these lists, we applied a typical case sampling method to select 'typical' first-tier suppliers. We then identified criteria for a 'typical' or 'average' first-tier supplier with the cooperation of focal firms as well as researchers and government officials. All these sources of recommendations were reviewed and analyzed together in selecting a 'typical' supplier. This process was repeated to select participants in the next tiers of suppliers until cassava farmers.

Within each supply chain, the sequence of data collection proceeds as follows. Firstly, we conducted in-depth interviews with governance officials and researchers to collect background information on cassava farming, trading and processing in the regions where these two supply chains are embedded. These interviews provided rough information on types and numbers of participants in these two supply chains. Secondly, we undertook in-depth interviews with focal firms in two supply chains. Thirdly, we traced the upstream linkages to the upstream-end of the supply chain(cassava farmers). The types and numbers of actors selected for in-depth interviews are shown in Table 1.

Semi-structured interviews were conducted using open-ended questions. The interviews lasted from 2 to 6 hours. Interview notes were written during the interviews by assistants. These notes were summarized by the authors with the cooperation of assistants after each interview.

We supplemented semi-structure interviews by collecting numerous documents and reports. These include firms' documents, contracts, account books and annual reports. Secondary data obtained from General Statistics Office, government reports, communes' reports and other publications was also utilized to provide background information of the two supply chains.
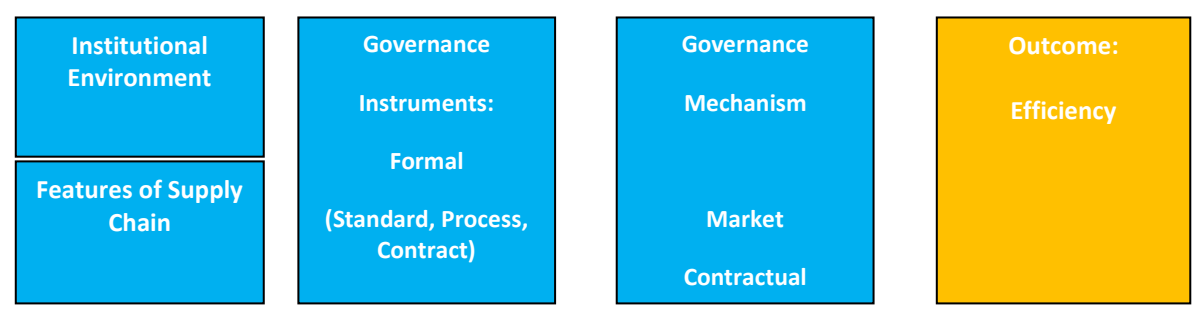

Figure 2. Conceptual Framework 
Table 1. Types and Numbers of Actors Interviewed

\begin{tabular}{lcc}
\hline \multicolumn{1}{c}{ Supply chain Actors } & Vedan Supply chain & Duong Lieu Supply chain \\
\hline Government officials & 1 & 2 \\
Commune leaders & 2 & 2 \\
Researchers & 3 & 2 \\
Managers of VEDAN Vietnam & 2 & 1 \\
Trading facilitators & & 3 \\
Cassava root producers & 3 & 1 \\
Cassava root brokers & & 2 \\
Cassava root traders & 2 & 3 \\
Wet starch processing firms & 2 & \\
Dry starch processors & 1 & $\mathbf{1 6}$ \\
Dry starch processing cum trading firms & 1 & $\mathbf{1 7}$ \\
Total & & \\
\hline
\end{tabular}

Source: Interviewed conducted by the author in two cassava supply chains

Table 2. Coding Scheme for Different Patterns of Governance

\begin{aligned} MR & (Spot) Market Relation \\ MR1 & Buyer and supplier deal with each other in a short-term orientation. \\ MR2 & $\begin{array}{l}\text { Repeat transactions are possible but the interactions (learning) and exchanges of information } \\ \text { between buyer and supplier are limited. }\end{array} \\$ MR3 & $\begin{array}{l}\text { The conditions of exchanging goods and services are negotiated every transaction on the basis of } \\ \text { market price. }\end{array} \\$ MR4 & Inspection on delivery. \\ CG & Contractual Governance \\ CG2 & Written Contract \\ CG3 & Standards are used as coordinating mechanisms. \\ CG4 & Transactions between two parties are frequent and idiosyncratic. \\ \hline RG & Relational Governance \\ RG1 & Both transacting parties have a long-term orientation in their inter-firm relationships. \\ RG2 & Frequent interactions and information exchanges between buyer and supplier. \\ RG3 & Trust and reputation are used as the coordinating mechanisms. \\ RG4 & There is a commitment between buyer and supplier to solve problems through negotiation rather \\ & than threat of exit. \\ RG5 & A risk sharing mechanism exists in inter-firm relationships between parties. \\ \hline $\boldsymbol{H} \boldsymbol{H} \boldsymbol{H} &$ Hierarchical Governance \\ HG1 & A firm is vertically integrated, in which several supply chain stages are integrated within the firm. \\ HG2 & The parent company controls its subsidiaries. \\ \hline Source: & Elaborated by authors based on Williamson, 1996; Jones et al., 1997; Gereffi et al., 2005. \end{aligned}

\section{Data Analysis}

To analyze data relating to transaction linkages, we adopted a pattern matching technique which involves in matching an observed pattern with a predicted (theoretical) one. Following the basic model of pattern matching by Trochim (1989, p.356), we first reviewed patterns of governance in different literature. The most common governance found in literature are: market-base relations, contractual, relational, hierarchical governance. We then developed specific criteria of inter-firm transactions for each of these governances (listed in Table 2). Since this research is an explanatory case study, the predicted pattern of different forms of governance is defined prior to data collection. During the data analysis stage, the study identifies criteria characterizing the inter-firm transactions between transacting parties in a dyadic relation (e.g. relation between a farmer and a trader) based upon data collected during the fieldwork. The matching criteria in each pattern of governance is described in research findings at section Supply Chain Structure and Transaction Linkages below. Based on the number of criteria matched in each pattern of governance, we identified the predominant pattern of governance for a specific dyadic relation. To analyze data of profitability within a supply chain, we adopted a 'Partial Budget 
Analysis'. Kaplinsky and Morris (2001) suggest that the best method for measuring profitability is to compute the returns to net assets. However, this method is irrelevant in the context of the agricultural sector in developing countries since detailed data to compute returns to net assets are often not available at both the farm level and firm level. ${ }^{1}$ In this context, we used the 'second best' measure, which computes profits and margins using partial budget data obtained from fieldwork. In this measure, margins and profits are calculated based on unit cost and unit price of a product produced or traded by each supply chain actor. The drawback of this measure is that the value of margins depends on the volume of sales and thus only partially reflects how profitable a business of particular actor is. The shortcoming of this measure is compensated by the data on volume of sales collected from the interviews.

\section{RESULT AND DISCUSSION}

\section{Institutional Context}

In the process of transition from the centrallyplanning economy to the market economy in Vietnam starting from 1986, series of macroeconomic and institutional reforms have been undertaken which effectively stimulate trade liberalization and the development of the non-state sector. For example, the introduction of foreign direct investment law in 1987 triggered a wave of foreign direct investment flowing into Vietnam. The radical reform program in agriculture in 1988 with three key pillars, namely reallocation of land to farm households for long-term use, introduction of a market mechanism, and liberalization of prices, gave farming households autonomy in production and exchange, and created the incentive for them to make resource allocation more efficient. The introduction of enterprise law in 1990 enables establishment and growth of the non-state sector. Consequently, the country has gained significant economic achievements. For example, annual average growth of GDP is 7\% (Ministry of Justice Of

\footnotetext{
${ }^{1}$ At the firm level, it is difficult to obtain this information as many firms fear government recrimination (e.g., tax collection) or access to such data by competitors.
}

Vietnam, 2013). However, the reforms of the judiciary system have been still slow. Weak contract enforcement has existed as part of 'business culture' and the use of the courts to solve disputes is uncommon because of the fears about the complications of lawsuits, the possibility of an unfair judge (Tran et al., 2009). For example, in a survey of 259 managers of non-state firms in Vietnam in 1995-97, only 9\% said that a court or other government agencies could help to solve their disputes (McMillan and Woodruff, 1999).

In short, the institutions of the market economy in Vietnam now are still incomplete. The legal system is not really effective. The current business environment is not truly equal and transparent. Domestic enterprises are in a very small size, and there are lacks of close ties among them (Ministry of Justice Of Vietnam, 2013).

\section{Supply Chain Structure and Transaction Linkages \\ Duong Lieu Supply Chain}

Duong Lieu is a craft village engaged in agrofood processing located in Northern Vietnam. Driven by the reform program in agriculture in Vietnam in 1988, Duong Lieu has been transformed from a place of formally subsistence agricultural production to a cluster of agro-food processing. Currently, Duong Lieu is the largest cassava and starch market center in the North of Vietnam. The cluster of agrofood processing firms in Duong Lieu produces both cassava-based final products that serve consumer goods market (such as candy, noodle, and alcohol) and intermediate inputs for industrial end-uses (such as wet starch, dry starch, and maltose) in the North of Vietnam.

\section{Duong Lieu's Supply Chain Structure}

The Duong Lieu supply chain has a fragmented structure, which is comprised of numerous small-scale farmers, brokers, traders, trading facilitators and starch processors participating in different activities along the supply network. There are many intermediaries between cassava farming and end-users cassava in Duong Lieu supply network. Among these, cassava roots traders play a coordinative role in the upstream of the Duong Lieu supply chain.

The upstream of the Duong Lieu supply network is composed of five stakeholders: (i) 
cassava farmers; (ii) cassava roots brokers; (iii) cassava root traders; (iv) trading facilitators; and (v) wet starch processors. Duong Lieu's supply network structure is presented in Figure 3 below.

Among these actors, only trading facilitators and wet starch processors are located inside the Duong Lieu commune. Cassava farmers, brokers and traders are located in the cassava farming areas in the North Mountainous Areas and the North Central Coast region.

\section{Transactional Linkages of Cassava Farmers}

There are three sale routes through which cassava farmers sell their products: (i) to cassava roots broker, (ii) to cassava roots traders, and (iii) to dry chips brokers.
The transactions between farmers and partners in all these routes are mainly characterized market governance. The transactions are short-term oriented in which price plays a decisive role in determining to whom farmers will sell their products (MR1). There are very limited information exchanges between farmers and traders or brokers. "We usual obtain market information from neighbors and relatives rather than trading agents" (interviews with cassava farmers) (MR2). Price is negotiated in every transaction (MR3).

The interviewed farmer revealed "We prefer selling to market as it gives us more flexibility, not binding to a fixed contract. Dealing with various buyers, we can get better price" (interviews with cassava farmers).

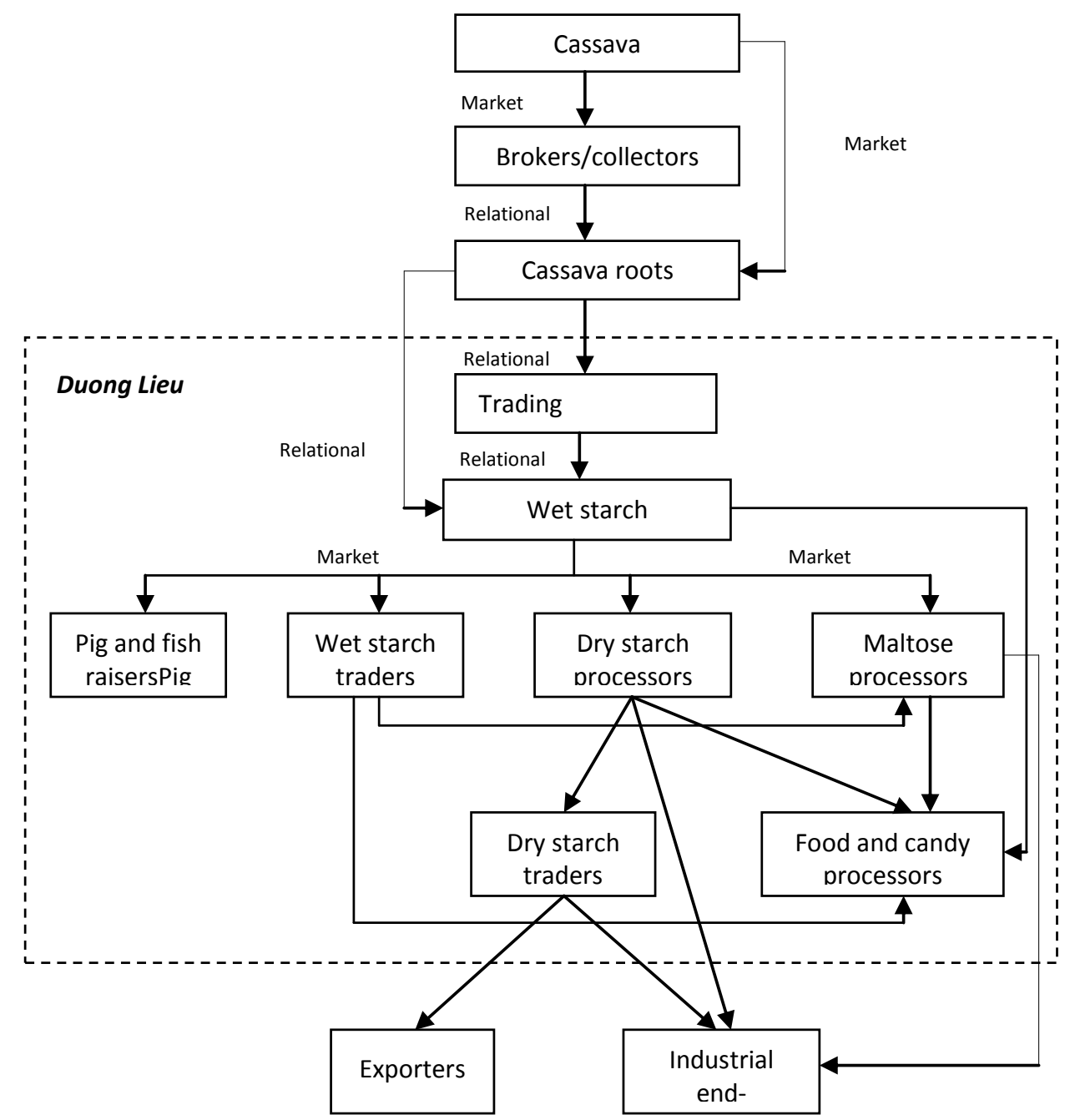

Figure 3. Interactions Between Actors in the Duong Lieu Supply Network 


\section{Transactional Linkages of Cassava Roots Brokers}

The trading network of a typical cassava roots broker comprises about 60 to 100 farmers on and some cassava roots traders. This network is built via a broker's personal relationships, typically neighbors, relatives, or past transactions.

On the backward side, transactions between brokers and farmers are characterized by a market governance. Their transactions may be repeated but not long-term oriented. Spot market transactions are preferred by both farmers and brokers in an effort to search for transactional flexibility as discussed above.

On the forward side, the transactions between brokers and cassava roots traders are characterized by relational governance. A broker often locks-in with a specific trader and their relationships are long-term oriented (RG1).There are some elements of information exchanges between the two parties (RG2). Disputes between brokers and cassava roots traders are solved by negotiations (RG4). "We have traded with some partners for a long time. It is easier to do business with the one we know than to a stranger especially when thing goes wrong, we can reconcile the conflict rather than run way" (interviews with cassava roots brokers and traders).

\section{Transactional Linkages of Cassava Roots Traders}

On the backward side, the transactions between traders and brokers are featured by a relational governance. Traders tend to use brokers to coordinate transactions with cassava farmers rather than to build direct relationships with farmers. "Farmers are very small and live dispersed geographical areas. It is more troublesome to buy from them than from brokers. The brokers we used are actually cassava farmers with whom we have long-term trading relations and who have good and wide relationships with neighboring farmers. They are wealthy and large farmers. For us, dealing with wealthy and large farmers is less risky than those who are poor" (interviews with cassava roots traders).

On the forward linkages, traders do not deal directly with very small and fragmented wet starch processors. They build a long-term relationship with a trading facilitator, who is responsible for facilitating and coordinating exchanges between traders and wet starch processors. The transactions between traders and trading facilitators are characterized by relational governance. Their transactions are recurrent and long-term oriented (RG1). Trading facilitators play a major role in transmitting market information in the processing area to cassava roots traders and, vice versa, traders are important sources of marketing information in the farming areas (RG2). Trust and reputation play a major role in coordinating transactions. Traders rely on trading facilitators in quality inspection (level of deterioration, starch contents of cassava roots) and price setting (RG3). Any disputes between two parties are solved through negotiation (RG4). There are some elements of risk sharing, in which wet starch processors commit to share risk in handling, quality loss during transportation, and misestimating the quality of cassava roots with trading facilitators (RG5).

\section{Transactional Linkages of Trading Facilitators}

On the backward linkages, transactions between trading facilitators and cassava roots traders are characterized by a relational governance pattern as discussed above.

On the forward linkages, transactions between trading facilitators with wet starch processors are characterized by a relational governance. The relationships are long-term and frequent, in which wet starch processors procure 80 to 90 percent of cassava roots via the trading facilitator (RG1). Their relationships are coordinated by trust and reputation. The evidence of the presence of trust is trading facilitators provide wet starch processors with cassava roots as trade credit. The payment to trading facilitator is delayed without incurring any additional charge until wet starch processors received payment from selling their outputs. Trading facilitators consider interest payment for the working capital used as trade credit given to wet starch processors is an important component of their cost structure. Wet starch processors also rely on trading facilitators in quality inspection and price setting (RG3).Trading facilitators and wet starch processors commit to share risk, 
especially in case of misestimating the quality (starch contents) of cassava roots (RG5).

\section{Transactional Linkages of Wet Starch Processors}

On the backward side of their supply network, wet starch processors are linked with a trading facilitator and a few cassava roots traders. The trading facilitator contributes to about 80 to 90 percent of the supply source. The link with a trading facilitator is featured by relational governance mentioned above. The cassava roots traders contribute to about 10 to 20 percent of the wet starch processor's supply source. "We also purchase cassava roots directly from cassava roots traders because the trading facilitator can only provide cassava roots for us to operate in about 25 to 27 days per month but we want to fully utilize family labor and processing capacity during the peak season" (interviews with cassava roots traders). The links between wet starch processors and cassava roots traders are characterized by a market governance. Transactions between them are short-term oriented (MR1). There are no information exchanges between two parties (MR2). The market price plays a decisive role in selecting the transacting parties in a specific transaction (MR3). The quality of cassava roots is inspected on each delivery (MR4).

On the forward side of their supply network, wet starch processors are linked with: (i) wet starch traders; (ii) dry starch processors; (iii) maltose processors; and (iv) food processors. Their transactions, despite the existence of trust in their relationships (RG3) in which payment may be delayed on a case-bycase basis, are mainly characterized by market governance. Their transactions are short-term oriented (MR1). "We do not find the necessity to build long-term relationships with buyers especially when they are not willing to share the risk of price fluctuations. The price of wet starch fluctuates over time, it is more flexible to sell to market. It is easy to find buyers" (Interviews with wet starch processors). There is limited information exchange between two transacting parties (MR2). The conditions of exchanges are generally based on the market price (MR3).

Overall, market and relational governance are the two mechanisms employed in Duong Lieu supply network and summarized in Figure 3 above.

\section{Vedan Supply Chain}

Vedan Vietnam (referred thereafter as Vedan) is a foreign invested firm that has been operating in the cassava and starch sector in the South East region of Vietnam since 1991. It is a major production base of Vedan International Limited which is an Asia's leading producer of fermentation-based amino acids, food additive products, biochemical products and cassava starch-based industrial products including modified starch, glucose syrup, soda, acid and beverages.

Vedan International markets its products in Vietnam, China, Europe, Singapore, Japan, Taiwan, ASEAN countries (other than Vietnam) and America under the Vedan brand name. In the company's market structure, Vietnam is the principal market. In Vietnam, to achieve cost-efficiencies, the main factor contributing to its competitiveness, Vedan has developed a large-scale vertical and horizontal integrated production system. This system is comprised of 'promoting the cultivation of agricultural raw materials, sourcing and processing to produce various end-use products' (Vedan International). This is particularly important since the competitiveness of Vedan relies considerably on its ability to access a large volume of raw materials at low costs.

\section{The Vedan's Supply Network Structure.}

The upstream of the Vedan supply chain consists of five main activities: (1) cassava farming; (2) cassava roots trading; (3) wet starch processing; (4) dry starch processing; and (5) starch trading. Vedan procures materials from four sources. $60 \%$ of materials are sourced from their subsidiaries and $40 \%$ are sourced from outside first-tier suppliers in the South East region of Vietnam (farmers, cassava roots traders, wet starch processing firms and dry starch processing cum trading firms). Vedan's supply network structure is presented in Figure 4.

The volume of cassava roots purchased by Vedan accounts for about 27 percent of the total production in this region. As a consequence, the purchase prices of cassava roots and starch (both wet starch and dry starch) released by Vedan are used as a 


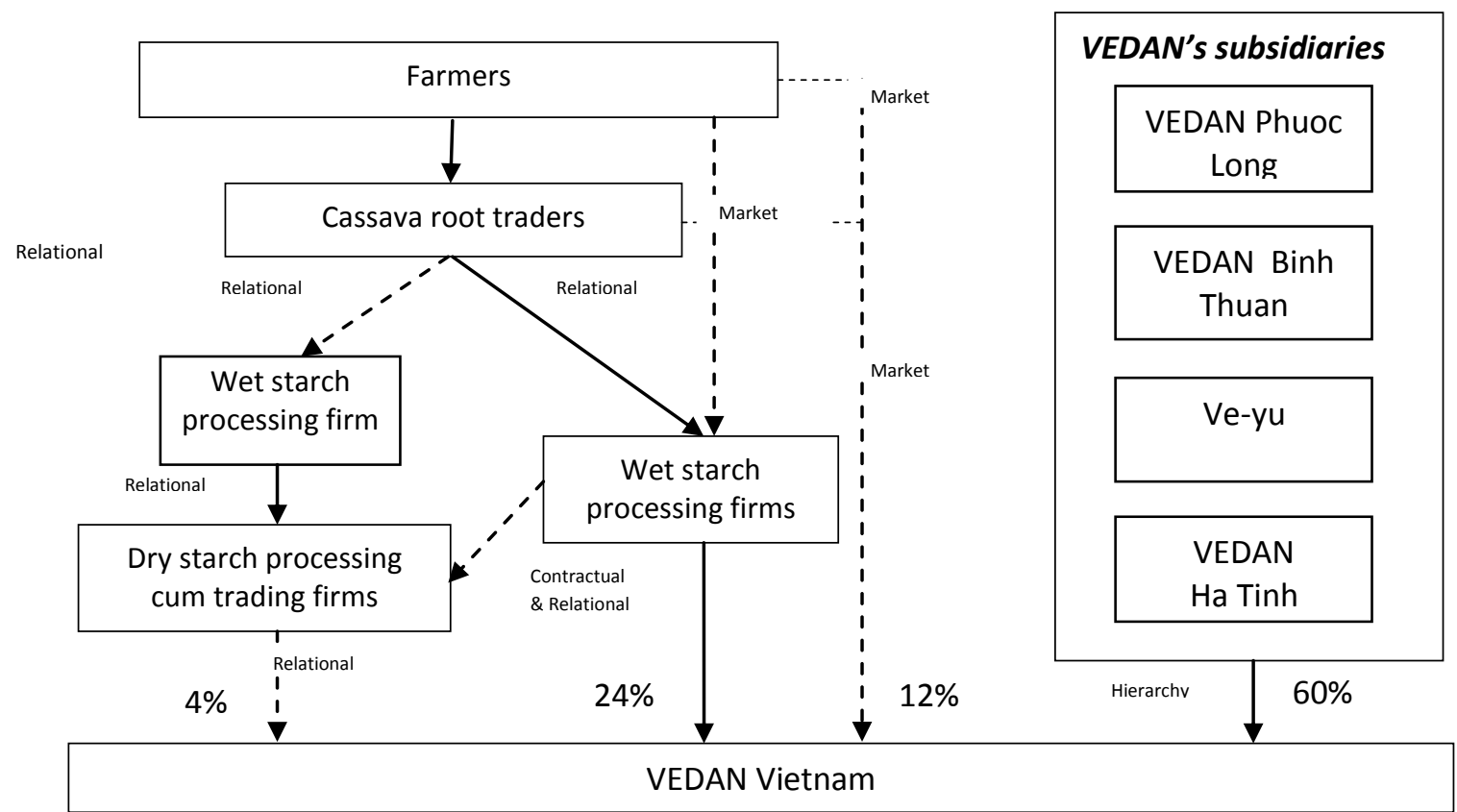

Figure 4. Interactions Between Actors in Vedan Supply Chain

reference for other firms in this region. The decisions of Vedan on what is to be purchased (either cassava roots, wet starch or dry starch) influence the decisions of other actors in the supply network.

\section{Transactional Linkages of Cassava Farmers}

There are two sale routes through which cassava farmers market their output: (i) starch processors like Vedan; and/or (ii) cassava roots traders.

Currently, the former route is estimated to deliver between 10 and 20 percent of cassava roots sales from farmers (interviews with farmers, traders, starch processors and researchers). Farmers' decisions of to whom cassava is sold are made upon their costs and benefits of using these two sale routes. By selling directly to starch processors like Vedan, farmers could get a higher price. However, they have to arrange labor and transportation to harvest and transport cassava roots to the processors' gates. This is costly for farmers, especially those who have to rely on hired labor for conducting those activities. An interviewed farmer explained 'The procedure for selling cassava roots to Vedan is too complex, we had go to Vedan to register the time and volume of cassava roots delivered for each transaction; then had to transport the cassava roots to the company gate if our proposals were approved, then queued for quality control, often taking between 3 to 7 hours, and had to return to the company in the next few days to receive payment from the company'.

Only large-scale farmers whose farm-gates are close by processor-gates and who have the capacity to mobilize labor for harvesting and transporting cassava roots prefer to sell cassava roots directly to starch processors (interviewed with cassava farmers, traders and starch processors). Only 12 percent of Vedan's materials come directly from farmers.

Linkages between farmers and starch processors are characterized by a market governance. Their exchanges have short-term orientation (MR1). 'I do not want to deal directly with farmers because they are small and not professional' (interviews with wet starch processors). There are limited information exchanges between two parties (MR2). Both of these two parties rely on the price of cassava roots released by Vedan as a reference. Exchanges between these two parties are conducted on a 'cash and carry' basis (MR3). Quality control is done on every delivery (MR4).

The linkages between farmers and traders, despite having one attribute to market governance in which negotiations of price are required in every transaction (MR4), are mainly characterized by relational governance. They 
have a long-term orientation in their relationships, in which traders provide inputs (including fertilizers, and varieties), services (extension service, land preparing, planting, weeding and harvesting) and medium-term financing as trade credit and advance payment for farmers (RG1). Information exchanges between these two parties are frequent, in which traders play a crucial role in transferring information of new varieties, fertilizers applications, farm management to farmers (RG2). The relationship between two parties is coordinated by a high level of trust built through neighboring relations (RG3).

\section{Transactional Linkages of Cassava Roots Traders}

On backward side, traders procure cassava roots from about 60 to 200 cassava farmers. Their linkages are attributed by a relational governance, which coordinates by trust and incentives (advance payment and trade credit). Their relationships are built through personal relationships, typically neighboring relations. "Keeping good relationship with my neighboring farmers provides me good information of the volume and quality of their outputs and also enables me to sell them inputs for farming"(interviews with traders)

On the forward side, traders sell cassava roots to between 3 and 5 wet starch processing firms, and/or Vedan. Traders use two distinct coordinating mechanisms to deal with these two types of buyers. The transactions between cassava roots traders and Vedan are featured by market governance. Their transactions are short-term orientation (MR1). Traders' decisions of whether to sell cassava roots to VEDAN Vietnam are generally based on the price released by VEDAN Vietnam in a noticeboard at its gate. There are no information exchanges between the two parties (MR2).Quality control is strictly required on every transaction (MR4).

The relationships between traders and other wet starch processing firms than Vedan are characterized by a relational governance. Both transacting parties have a long-term orientation (RG1). An interviewed manager of wet starch processing firm said by building long-term relationships with some traders, we can secure volume of cassava roots for processing'. There is evidence of a high level of trust in their transactions (RG3). An interviewed manager of wet starch processing firm said 'I am willing to provide advance payments when needed. Of course only to the traders I trust'. There is evidence of a risk sharing mechanism existing between the two parties, in which they are willing to share risk arising from price fluctuations (RG5).

Among these two types of buyers, wet starch processing firms and Vedan, traders prefer to sell cassava roots to the former since they are willing to provide advance payments and because of strict quality control by Vedan (interviews with traders).

\section{Transactional Linkages of Wet Starch Processing Firms}

On the backward side, wet starch processing firms are linked with: (i) a number of cassava farmers; and (ii) about 5 to 10 traders. They use different mechanisms to coordinate exchanges with these two parties.

The transactions between the firms and farmers are coordinated by market governance as analyzed above. 'We only buy directly from farmers when we are in shortage of materials. Farmers do not have skills in trading and fulfillment of sale procedures. Purchasing cassava roots from them takes more time and is costly compared to traders. (An interviewed owner of a wet starch processing firm said).

The linkages between wet starch processing firms and traders are coordinated by a relational governance as analyzed above. 'Some traders have dealt with me since $1994, \ldots$ the key factor to keep these long-term relationships is that I am willing to share risk of price fluctuations. I paid slightly higher than market price to assist them cover their losses' (interviewed owner of wet starch processing firm revealed).

On the forward side, wet starch processing firms are linked with: (1) Vedan; and (2) other buyers of wet starch (mainly endusers of wet starch). The former represents about 80 to 90 percent of the wet starch processing firms' sales volume. 'Although Vedan offers lower price than other buyers, we prefer to sell to them because they provides large and frequent orders, its easier payment procedure, and no risk of payment failure' (interviews with wet starch processing firms). The linkages between wet starch processing 
firms and Vedan are characterized by contractual governance. The transactions are formalized in written contracts (CG1). Vedan uses formal quality control process (CG2). we have been dealing with Vedan since 1998 but they still strictly inspect every delivery. The Vedan's inspection workers often randomly take five samples from 1 truck delivered'. (interviewed manager of wet starch processing firm said).

However, the transactions between wet starch processing firms and Vedan are also characterized by relational governance. Their relationships are long-term oriented (RG1). "Vedan is keen on supporting wet starch processing firms to expand capacity because this enable us to secure supply"(interviewed Vedan's manager said).There is evidence of information exchanges between the two parties, particularly market information concerning prices, demand and supply of cassava roots and wet starch (RG2). This information is exchanged by telephone or direct meetings (interviews with Vedan manager).There are some elements of risk sharing in which Vedan is willing to share the risk and uncertainty with its wet starch suppliers on a case-by-case basis (RG5). A wet starch processing firm reported that 'the contract between Vedan and my firm had been signed, which specified price and the volume of wet starch, but Vedan does not require me to strictly follow the contract's terms..., in the case of unfavorable price fluctuations for my firm, Vedan might adjust its procurement price on a case-by-case basis' (an interviewed manager of wet starch processing firm said)

The relationships between wet starch processing firms and their buyers, other than Vedan, are coordinated through market governance: (1) a short-term orientation (MR1); (2) limited information exchanges between transacting parties (MR2); and (3) price of wet starch are negotiated in every transaction (MR3).

\section{Transactional Linkages of Dry Starch Processing Cum Trading}

On the backward side, dry starch processing cum trading firms deal with about 5 to 10 medium-sized wet starch processors. Their linkages, despite having one attribute of market governance in which quality control is done on every delivery (MR4), are mainly characterized by a relational governance. They have a longterm orientation in their relationships (RG1).There is some evidence of frequent information exchanges (RG2).Trust and reputation are used as the coordinating mechanism (RG3). 'We often provide advance payment to wet starch processors to enable their business and provide us materials'(interviewed owner of dry starch processing cum trading firm said)

On the forward side, they are linked with two parties: Vedan and about 2 to 3 other endusers of dry starch, in which Vedan represents about 77 percent of their sale volume. The relationships of a dry starch processing cum trading firm with their buyers are coordinated by different mechanisms.

Their linkages with Vedan, despite having one attribute to market governance in which Vedan strictly inspects the quality on every delivery (MR4), are mainly characterized by relational governance. Both Vedan and dry starch processing cum trading firms have a long-term orientation in their relationships (RG1). 'Developing the capabilities of our suppliers, especially the capability in providing a large-volume and reliable supply is critical to reduce our costs'(interviewed Vedan's manager said).There is evidence of information exchanges between two parties (RG2). 'I keep frequent exchange of information with Vedan's staff, especially information concerning prices, demand and supply of cassava roots, starches and starch end-uses in local markets'. (interviewed owner of a dry starch processing cum trading firm said). There is evidence of the presence of trust. Vedan provides advance payment for transacting parties or acts as a guarantor for their borrowing from an assigned commercial bank (RG3). This advance payment facilitates dry starch processing cum trading firms to fulfill the orders from Vedan (interview with a dry starch processing cum trading firm).

The relationships between dry starch processing cum trading firms with other buyers (typically end-users of starch such as animal feed processors), are mainly characterized as a market governance: no long-term orientation in their relationships (MR1); limited information exchanges between the two parties (MR2); and 
strict quality control on every transaction (MR4).

\section{Transactional Linkages of Vedan with partners}

Vedan sources $60 \%$ of materials from their subsidiaries. Transactional linkages between

Vedan and its subsidiaries in Vietnam are characterized by hierarchical governance. Governance mechanisms employed in Vedan supply network are summarized in Figure 4 above.

\section{Supply Chain Performance}

\section{Duong Lieu Supply Network Performance}

The interviews with a trading facilitator and wet starch processors in Duong Lieu show that the average conversion ratio between cassava roots and wet starch is: $1 \mathrm{~kg}$ of cassava roots = $0.435 \mathrm{~kg}$ of wet starch.

Based on this ratio, we estimated marketing margins and profits along the upstream of the Duong Lieu supply chain, using partial budgets data collected from interviews with actors along major linkages. Evidence from the interviews with various actors involved in the upstream of the Duong Lieu supply chain reveals that about 80 percent of cassava roots traded in Duong Lieu is delivered through the linkages illustrated in Figure 5.

The result of the calculation of marketing costs, margins and profits for the main marketing channel in the upstream of the Duong Lieu supply chain are presented in Table 3 and Figure 6.

Figure 6 shows that farmers contribute to the highest share of total cost (61.8 percent) in the upstream of the Duong Lieu supply chain. They also capture the highest share of total profit in that chain (80.2 percent). However, the partial budgets method hides the fact that although farmers gain a high return from $1 \mathrm{~kg}$ of cassava roots sold, their total income from cassava production is very low due to their low level of output.
Table 3. Distribution of Marketing Costs, Margins and Profits along the Upstream of the Duong Lieu Supply Chain

\begin{tabular}{lccc}
\hline & $\begin{array}{c}\text { Marketing } \\
\text { costs } \\
(\%)\end{array}$ & $\begin{array}{c}\text { Margins } \\
(\%)\end{array}$ & $\begin{array}{c}\text { Profit } \\
(\%)\end{array}$ \\
\hline Farmers & 61.8 & 66.3 & 80.2 \\
Brokers & 0.3 & 0.9 & 2.8 \\
Traders & 26.4 & 22.3 & 9.7 \\
$\begin{array}{l}\text { Trading } \\
\text { facilitators }\end{array}$ & 1.5 & 1.7 & 2.2 \\
$\begin{array}{l}\text { Wet starch } \\
\text { processors }\end{array}$ & 10.0 & 8.8 & 5.1 \\
\hline Total & 100.0 & 100.0 & 100.0 \\
\hline
\end{tabular}

Source: Primary data analysis

For cassava roots traders, they receive a low share of income compared to their contribution to the total cost. The main determinant of traders' profitability is volume rather than margins. The traders lack of expertise and market knowledge. They rely on trading facilitators for quality inspection and price setting. Instead of making investments in expertise and market knowledge, they focus on maximizing their volume of cassava roots traded.

Similar to cassava roots traders, wet starch processors obtain a relatively low profit share, compared to their contribution to the total cost. Earnings of wet starch processors mainly rely on their ability to utilize family labor and residue as feed stuff or animal farming. As a consequence, wet starch processors have no incentive to expand their processing scale.

The actors of a supply chain are mostly interested in utilizing existing resources for maximizing output rather than improving quality of their business. There is no evidence of investment in improving productivity along the supply chain. Low conversion rate or low efficiency lead to high cost and low profitability compared to those in the other supply chain to be analyzed thereafter.

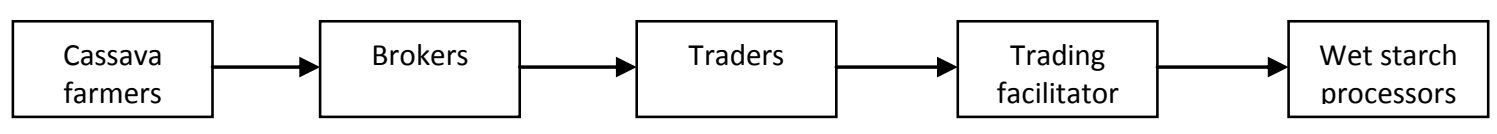

Figure 5. Major Marketing Channel in Duong Lieu Supply Network 


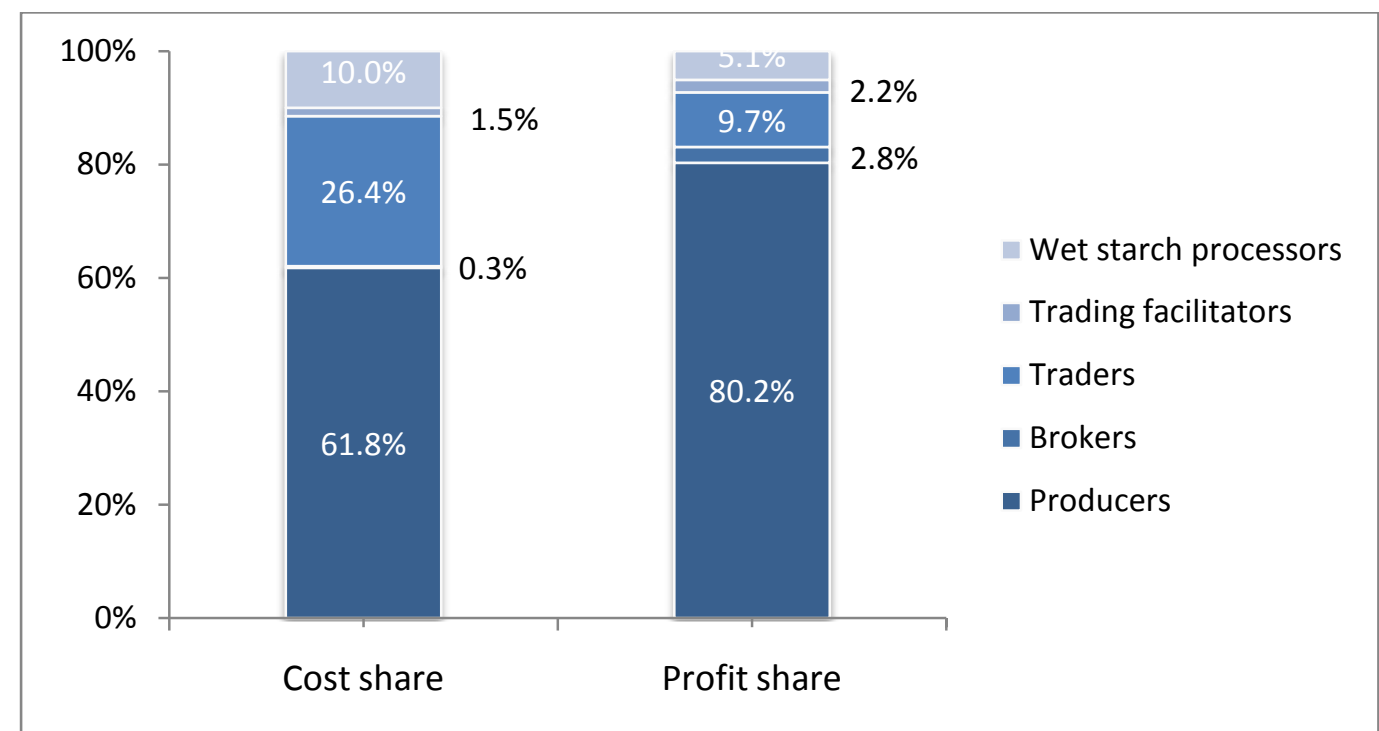

Source: Calculated by The Authors Based on Interviewed Data of Cost Structure of Each Participant Figure 6. Cost and Profit Shares Between Actors in Duong Lieu Supply Network

\section{Vedan Supply Network Performance}

Information obtained from the interviews with traders and wet starch processing firms shows the average conversion ratio between cassava roots and wet starch in the Vedan supply chain is: $1 \mathrm{~kg}$ of cassava roots $=0.5 \mathrm{~kg}$ of wet starch.

Based on this ratio, we estimate marketing margins and profits along the upstream of the Vedan supply chain, using partial budgets data collected from interviews with Vedan and its external suppliers in the major linkage which contributes to 24 percent of Vedan's cassava-based inputs and is illustrated in Figure 7.

The result of the calculation of marketing costs, margins and profits for the main marketing channel in the upstream of the Vedan supply chain are in Table 4 and Figure 8.

Table 4. Distribution of Marketing Costs, Margins and Profits between Actors Vedan Supply Network

\begin{tabular}{|c|c|c|c|}
\hline & $\begin{array}{c}\text { Marketing } \\
\text { costs } \\
(\%) \\
\end{array}$ & $\begin{array}{c}\text { Margins( } \\
\%)\end{array}$ & $\begin{array}{c}\text { Profit } \\
(\%)\end{array}$ \\
\hline Farmers & 50.5 & 58.8 & 64.84 \\
\hline Traders & 28.0 & 24.3 & 21.54 \\
\hline $\begin{array}{l}\text { Wet starch } \\
\text { processing } \\
\text { firms }\end{array}$ & 21.5 & 16.9 & 13.62 \\
\hline Total & 100.0 & 100.0 & 100.0 \\
\hline
\end{tabular}

Table 4 shows that farmers contribute the largest share of marketing costs incurred per each ton of wet starch marketed. They also capture the largest share of profits generated in the channel. Traders and wet starch processing firms rank the second and third, relatively, both in terms of their contributions to marketing costs and profits received.

Profit per each ton of cassava roots traded generated in the Vedan supply chain is about double that of the Duong Lieu supply chain, because of the lower marketing costs incurred in the Vedan supply chain. As a result, the profits that actors participating in the Vedan supply chain receive per each ton of cassava roots traded are much higher than those of the Duong Lieu supply chain. Furthermore, the total profit that each actor participating in the Vedan supply chain receives is much higher than those involved in the Duong Lieu supply chain as their scale of businesses are much larger.

In the Vedan supply chain, although farmers capture the highest share of profit generated per each ton of dry starch produced, the total profit that each farmer received is relatively low compared to other participants due to the difference in their scale of businesses. Evidence from the interviews with various actors in Vedan supply chain suggests that expenditures in improving capability, expertise and network relationships are the key determinants of their profitability. 


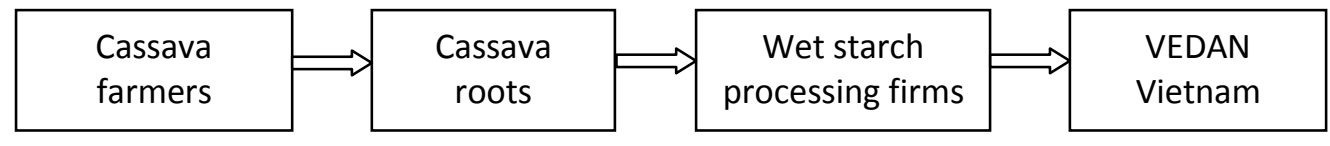

Figure 7: Major Marketing Channel in Vedan Supply Network

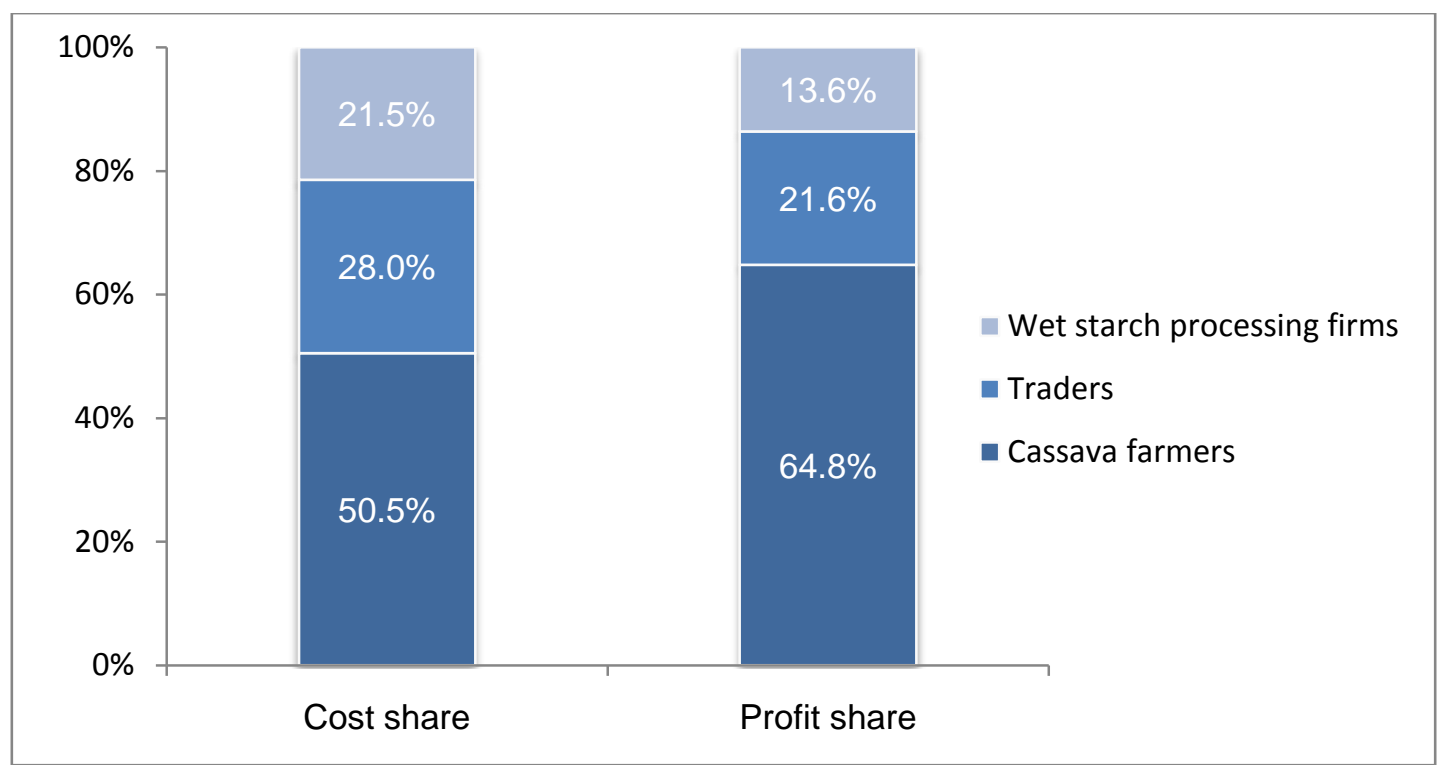

Figure 8. Cost and Profit Shares Between Actors in Vedan Supply Network

For farmers, their profitability is determined by farm management method. For traders, expertise and capability in providing inputs for farmers and in building a trading network, which is coordinated by a high level of trust and reputation, play a crucial role in determining their profitability. Similarly, the capability in a high-volume supply, expertise, and the ability to build a secure procurement network are determinants of profitability of wet starch processing firms. Since the profitability is determined largely by capability and expertise rather than the maximization of the volume of output, participants in the Vedan supply chain have incentive to make investments in improving their performance and competitiveness. These investments enable them to capture a higher share of profit generated in that chain.

Influence of Institutional Context, Supply Chain Structure, Product Characteristic on Governance and Performance.

Supply Chain Structure, Governance and Performance

The Duong Lieu supply chain is featured by a fragmented structure. It has many layers of small-scale actors. The small farmers tend to avoid using purchased inputs for cassava farming, partly owing to the fragmentation of land preventing efficient uses of inputs and there are no parties willing to provide inputs as trade credit. Small farm size and low productivity contribute to the low cassava output per cassava farmer. High transportation costs due to the long distance from cassava production areas to the processing areas, poor transportation conditions and limited infrastructure use in cassava commerce cause high logistic costs for the whole supply network. The high costs of coordinating a number of very small farmers and processors, and the fear of the failure of the former collective arrangement still acts as a path dependent matter impeding collective action which reduce efficiency of the chain. The constraints of Duong Lieu's fragmented supply structure leads to higher transaction costs and risks while at the same time creating barriers for stakeholders locked into the Duong Lieu supply chain to upgrade their business. As a result of high transaction and coordination costs, and the existence of numerous intermediaries between cassava farming and 
processing, marketing margins and profits generated in this chain are low.

Stakeholders participating in the Duong Lieu supply chain either avoid investing in relationship. For cassava roots traders, they change their 'transaction interface' to minimize expenditures on these investments. For wet starch processors, they still use out of date technology and rely on trade credit as well as facilitation and coordination services provided by trading facilitators rather than building capabilities to deal directly with traders. This eventually leads to a low level of relationship investments, a mean to capture higher share of profit, embodied in transactions along the supply chain. In this type of supply chain structure, firms have low incentive to mitigate uncertainty through vertical integration. Instead, they seek to stabilize their relationships with transacting parties to reduce transaction costs and avoid investing in the relationship. Therefore, the process of mitigating uncertainty in the Duong Lieu supply chain leads to a greater fragmentation in the supply chain structure and low supply chain efficiency.

In contrast to the Duong Lieu supply chain, there is evidence of concentration and vertical integration of supply chain activities in the Vedan supply chain. It is comprised of highly commercialized farmers, and mediumand large-scale export oriented processing firms. Vedan promotes the cultivation of cassava roots and starch processing in order to ensure a secure and consistent supply for its operation. The provision of new varieties, inputs, technical assistance, medium-term financing of Vedan to farmers under the contract farming program has quickly shifted cassava from a traditional food crop with low productivity to an industrial crop. This promotion has boosted the cassava production in the South East region, where Vedan located its production bases, in terms of both area expansion and productivity increase. These lead to high efficiency of the whole supply chain. It is clear that Vedan's supply chain structure enable them to combine different governance mechanism which help to improve efficiency of the supply network. Based on the findings of the both cases, we, therefore, propose that

Proposition 1: Supply chain structure influences firms' choice of supply chain governance which in turn affects supply chain outcome.

\section{Legal Institution, Supply Chain Structure and Governance}

The existence of a weak legal system for transactional assurance in emerging market correlates to Vedan's choice of governance. Vedan set up subsidiaries to provide them with materials and only purchase $40 \%$ of their materials from outside suppliers. Vedan could purchase only 12 percent of cassava roots specified in the written contracts. The company did not take its disputes with opportunistic partners to court. "We never brought the disputes to the courts as they were ineffective, valuable time would be lost in court" (interviewed manager of Vedan). In respond to ineffective legal system, they configure their supply network using multiple governance mechanism which consist of $60 \%$ of hierarchy, 24 percent of contractual and relational, and 12 percent of market-based to govern its supply network. Vedan case shows that legal institution does affect on the firms' choice of supply network governance.

However, in the Duong Lieu supply chain, there is no evidence supporting for a relationship between the legal system and governance choice. This is partly because of the fragmented nature of the Duong Lieu cassava supply chain. Duong Lieu supply chain consists of a number of very small-scale supply chain actors, particularly cassava farmers and starch processors. Most of their transactions are very small, particularly exchanges between cassava roots traders and cassava farmers. These small-size transactions are likely beyond the reach of the court since parties have no incentive to take small transactional disputes to court regardless of the effectiveness of the court. In this context, firms respond by restructuring their transactions to minimize the potential for the breach at their transaction interfaces. Transactions are conducted primarily on an arm's-length basis, particularly when they involve small-scale farmers.

Therefore, the existence of a weak legal system for transactional assurance in emerging market alone did not lead to the use of relational governance as predicted by research of institutional school. Also Vedan does not rely on relational governance to coordinate 
economic transactions. Relational governance only account for $24 \%$ of Vedan governance structure.

The findings from both cases indicate the combination of supply chain structure and the ineffective legal system influence the choice of governance. When supply chain has fragmented structure, weak legal institution does not affect on a firm's choice of supply chain governance. When supply chain has concentrated structure, weak legal institution affect on a firms' choice of supply chain governance. We, therefore, propose that

Proposition 2: Legal institution affects firms' choice of supply chain governance and the degree of the degree of the effect is adjusted by supply chain structures.

\section{Socio- Economic Institution and Supply Chain Structure}

Despite the fact that both supply chains locate in the same country, there are some differences in socio economic institutions in the North where Duong Lieu supply locates and in the South where Vedan supply chain situates. Before 1988, due to the socialist ideology adopted by the government, agricultural production in Northern Vietnam was highly collectivized and not commercialized. After the reform, farming lands in the North were divided into small allotments and given to each household for freely farming and selling products in markets. Consequently, cassava farming in the North became commercialized but fragmented. Different from the North, agricultural production in the South of Vietnam has been highly commercialized due to freemarket ideological perspective inherited from America influences before the country's unification in 1975. While in the Northern part, about $40 \%$ of cassava production is still used for non-farm consumption, in the Southern part of the country, cassava is mainly grown for cash income with more than $80 \%$ of total production is marketed for starch processing, particularly in the South East where cassava production is highly commercialized. These differences in socio-economic institution lead to differences in supply chain structure and choice of supply chain governance.

Cassava farming land in Vedan supply chain is less fragmented compared to the land in the Duong Lieu. This enables the application of new varieties, inputs and new farming management methods in cassava farming. Furthermore, growth of the industrial sector in the South East region where Vedan supply chain locates has absorbed labor from the agricultural sector and facilitates the land consolidation process. The South East region, where most of factories are located, has good transportation conditions. This reduces transportation costs and facilitates the development of the whole cassava and starch sector in the region. Most of large-scale and export-oriented factories are located in the South East region because of its good infrastructure. The concentration of these factories in the region has facilitated the commercialization and expansion of the cassava and starch industry. These factors force stakeholders to follow standard and formal procedure to improve efficiency. The transactions between Vedan and external suppliers are governed by standard and formal procedure but trust and corporative willingness are two decisive instruments for keeping long term mutual benefit relationships.

In Duong Lieu supply chain, cassava farming is fragmented and cassava processing is at small scale. Although cassava starch processing capacity has also increased during the last two decades and production has shifted from manual to semi-mechanized processing, most of these businesses are still predominated by household units at a very small scale rather than horizontal cooperation in any business associations (interview with commune leaders). "With experience of failure of the socialism system in the past, we disbelieve in formally collective arrangements" (interviewed wet starch processor in Duong Lieu said). This socio-economic history prevents actors participating in the Duong Lieu supply chain from engaging in such a form of joint action to achieve collective efficiency, and thereby the choice of supply governance.

Based on the findings of the both cases, we, therefore, propose that

Proposition 3: Socio-economic institution influences on supply chain structure which in turn affect firms' choice of supply chain governance. 


\section{Product characteristics, Supply Chain Structure and Governance}

A high level of uncertainty involved in a transaction raises the risk of higher transaction costs. Two types of uncertainty including environmental uncertainty and behavioral uncertainty influence on transaction costs and thereby choices of governance in the Duong Lieu supply chain and the Vedan supply chain.

In both Vedan and Duong Lieu supply chain, supply uncertainty relates to the unpredictable nature of the quantity, quality and timeliness of the cassava roots supply. It is reported that starch processors in both supply chains are faced with difficulty in finding a secure volume of cassava roots for operating at full production capacity. In addition, they also suffer from the problem of a heterogeneous quality of the cassava roots supply. In the cassava and starch sector, supply uncertainty is related to the technical properties (product characteristics) and the farming characteristics of cassava roots.

The cassava roots have three attributes that affect transaction costs including: perishability, quality heterogeneity, and bulkiness. These characteristics raise the complexity of transaction and hence transaction costs. However, evidence from the two case studies how that these product characteristics have different impacts on transaction costs.

In the Duong Lieu supply chain, the characteristics of perishability and bulkiness severely raise transaction costs, especially transportation and coordination costs. This is because of: (i) the distance from cassava farming areas to cassava processing areas is long; (ii) cassava farming areas are often located in the mountainous areas where transportation conditions tend to be poor;(iii) the Duong Lieu supply chain mainly consists of very small-scale actors operating along the supply chain, particularly cassava farmers and starch processors. The fragmentation of farming and processing activities in Duong Lieu cause high transportation costs for collection and distribution of cassava roots. At the same time, they require a greater coordination of collection and distribution activities and result in high coordination costs.

In the Vedan supply chain, participants do not face severe transaction costs arising from the characteristics of the perishability and bulkiness of cassava roots because cassava farming and processing are localized and on large scale. Most participants are located in the South East region, which has good transportation conditions. These enable short lead time thereby reduce costs arising from the characteristics of the perishability and bulkiness of cassava roots.

The findings from the both cases suggest that product characteristics influence on transaction cost and therefore choice of governance. However, the effect is moderated by supply chain structure. The effect is high when supply chain is fragmented and low when supply chain is highly concentrate. In other words, we propose that

Proposition 4: Product characteristic influences on firms' choice of supply chain governance but the degree of effect is adjusted by supply chain structure.

\section{Relationship Investment and Governance}

In order to participate in a specific transaction relation, an actor has to make expenditures in building relationships. These expenditures create barriers to entry into a specific transaction relation and cannot be easily and fully converted if the relation is terminated. Through the in-depth interviews with various actors participating in the VEDAN value chain and the Duong Lieu value chain, we found that barriers to entry into a specific transaction relation along these chains comprise: (1) a high level of working and fixed capital; (2) accumulated market knowledge and expertise of firms' owners on the cassava and starch markets; and (3) reputation of firms in the cassava and starch sector.

Transactions in the Duong Lieu supply chain are characterized by a relatively low level of expenditures in the relationship investments, especially in comparison to those in Vedan supply chain. With low level of relationship investment, relational governance is popular in Duong Lieu supply network governance structure while firms in Vedan supply network diversifies governance structure rather than relying relational governance. The evidences suggest that relationship investment affects firms' choice of supply chain governance. We therefore, propose that 


\author{
Proposition 5: Relationship investment \\ influences firms' choice of supply chain \\ governance.
}

\section{CONCLUSION}

This paper investigates how transactions between firms are organized in the absence of an effective legal system for transactional enforcement and effect on the governance on network outcomes.

We explored firms' choices of governance in a specific context of Vietnam, where legal institution is characterized by a weak legal system for contractual enforcement and socio-economic institution is characterized by transition from central planning into market mechanism.

Our findings indicate the correlations among institutional context, supply chain structure, product characteristic, relationship investment and firms' choices of governance which correlates to efficiency of supply network. We found that supply chain structure is a significant determinant of firms' choice of governance. Apart from its direct effect on firms' choice of governance, supply chain structure also moderates the effect on legal institution and mediates the effect on socioeconomic institution on firms' choice of governance.

Our findings show that institutional environment influences a firm's decisions about governance patterns under certain conditions. Legal institution matters only when supply chain structure is highly concentrated and does not matter when supply chain structure is fragmented. We also found that the relational governance pattern is not the only way to cope with a weak legal system for transactional assurance. Instead, there is evidence that firms reconfigure their supply chains to avoid investing in the relationship and thus, minimize the associated transaction costs. Socio-economic institution indirectly influences on firms' choice of governance through the mediating impact of supply chain structure. Our study contributes to the ongoing theoretical debate of how inter-firm transactions are organized as the followings:

First, this study points out that firms' decisions about alternative governance patterns to conduct their economic transactions are influenced by the combination of three main factors: (i) the institutional environment; (ii) supply chain structure (iii) product characteristics. Prior studies have found that firms in a number of transitional economies have to rely on the relational governance to compensate for the unreliable legal system for contract enforcement. Our research shows that this explanation of governance remains incomplete since it ignores other factors determining governance structure such as transaction characteristics and the characteristics of the production processes. The evidence from two case studies, i.e. the Vedan and Duong Lieu supply chain shows that institutional environment alone would not lead to the use of a relational governance.

Second, our study points out that not only legal institution but also socio-economic institution in transition economy influence on transaction cost and therefore firms' choice of governance and outcome.

Third, our study develop propositions of the effects of institution environment, supply chain structure, production characteristic, relationship investment on firms' choice of supply chain governance and outcome.

Our study provides following managerial implications. Firstly, we suggest that the relational governance is inadequate for transactional assurance under the absence of an effective legal system for transactional enforcement and high entry barrier for relationship development. In case of a foreign firm like Vedan entering an emerging market like Vietnam, developing relationship with local partners is not an easy task. Managing a network of small farmers leads to high coordination cost. A firm should reconfigure their supply chains so that the complexity of transaction is minimal at the transaction interfaces. This enables them to mitigate uncertainties and the associated transaction costs, particularly the coordination costs of transacting business. Specifically, in case a production network is very fragmented, farmers are very small and locate in dispersed geographical areas, it is more troublesome to buy directly from them than from brokers or traders. Vertical integration does not appear as a good solution in case of fragmented farming land and land ownership. Using social ties to manage transaction with key first tier suppliers 
appears to be good practice. In case of supply network is concentrated, especially, farming lands are on large scale, vertical integration seems to be the most preferable. The second best option is to develop relational governance with large suppliers and keep small portion of procurement from spot market.

Despite the above contributions, this study has limitations. Our ground theory building is based on small number of observation. More observations from other supply network will strengthen our propositions. Although using closed coding scheme are useful in matching an observed phenomena with a theoretical one, it can't capture a large variety of phenomenon in practice, particularly since these patterns tend to vary in specific industries and places. For example, the existence of an intermediate governance (mixed between contractual and relational) between Vedan and its wet starch suppliers is a case in point. To capture the diversity of governance mechanism in practice, an open-ended coding scheme will be useful. Our analysis of financial performance based on partial budget analysis method has some drawbacks. Future research should find a better approach to measure financial performance within supply network.

\section{REFERENCES}

Andersen, P.H., and Christensen, P.R. 2005. Bridges over Troubled Water: Suppliers As Connective Nodes In Global Supply Networks. Journal of Business Research, 58 (9), $1261-1273$.

Bair, J. 2005. Global Capitalism and Commodity Chains: Looking Back, Going Forward, Competition and Change. SAGE Journals, 9 (2), 153 180.

Davis, L. E. and North, D.C. 1971. Institutional Change and American Economic Growth. Cambridge: Cambridge University Press

Gereffi, G., J. Humphrey, and T. Sturgeon. 2005. The Governance of Global Supply Chains. Review of International Political Economy, 12 (1): 78-104.

Granovetter, M. 1985. Economic Action and Social Structure: The Problem of
Embeddedness. American Journal of Sociology, 91, $481-510$.

Gulati, Ranjay. 1995. Does Familiarity Breed Trust? The Implications of Repeated Ties for Contractual Choices in Alliances. Academy of Management Journal, 38, 85 -112 .

Johnson, Simon; Kaufmann, Daniel and Shleifer, Andrei. 1997. The Unofficial Economy in Transition. Brookings Papers on Economic Activity, 2, 159 221.

Johnson, S., and Loveman, G. 1995. Starting Over in Eastern Europe. Boston: Harvard Business School Press.

Johnson, S., McMillan, J., and Woodruff, Christopher. 2002. Courts and Relational Contracts. Journal of Law, Economics, and Organization, 18 (1), $221-277$.

Jones, C., Hesterly, W. S., and Borgatti, S. P. 1997. A General Theory of Network Governance: Exchange Conditions and Social Mechanisms. Academy of Management Review, 22 (4), 911 - 945.

Lorenz, E. 1988. Neither Friends nor Strangers: Informal Networks of Subcontracting in French Industry in D. Gambetta (ed.), Trust - Making and Breaking Cooperative Relations. Oxford: Basil Blackwell.

McMillan, John. 1997. Markets in Transition. Advances in Economics and Econometrics: Theory and Applications, (ed.) David M. Kreps and Kenneth Wallis. Cambridge: Cambridge University Press.

McMillan, J., Woodruff, C. 1999. Dispute Prevention Without Courts in Vietnam. Journal of Law Economics and Organization, 15 (3), $637-658$.

McMillan, J. and Woodruff, C. 2002. The Central Role of Entrepreneurs in Transition Economies. Journal of Economic Perspectives, 16 (3), 153 170.

Ministry of Justice of Vietnam. (2013/12/10). Institutional Improvement and Legal Reform in Vietnam. Retrieved from 
http://moj.gov.vn/en/ct/Lists/TalkingLaw s/View_Detail.aspx?ItemID=108

North, D. 1990. Institutions, Institutional Change and Economic Performance. Cambridge: Cambridge University Press.

Patton, M. 1990. Qualitative Evaluation and Research Methods. $2^{\text {nd }}$ ed. USA: Sage Publication.

Peterson, H.C., Wysocki, A. and Harsh, S.B. 2001. Strategic Choice Along The Vertical Coordination Continuum. International Food and Agribusiness Management Review, 4, 149 - 66.

Pilbeam, Colin., Alvarez, Gabriela and Wilson, Hugh. 2012, "The Governance of Supply Networks: A Systematic Literature Review". Supply Chain Management: An International Journal, 17 (4), 358 - 376.

Tesco.com. (2015/11/10). Retrieved from http://www.tesco.com/groceries/product/ details/?id=264388430
Thorelli, H. 1986. Network Between Market and Hierarchy. Strategic Management Journal, 7 (1): 37 - 51.

Tran, T.B., Grafton, R.Q., and Kompas, T. 2009. Institutions Matter: The Case of Vietnam. The Journal of SocioEconomics, 38(1), 1 - 12.

Trochim, W. M.K. 1989. Outcome Pattern Matching and Program Theory. Evaluation and Program Planning, 12, $355-366$.

Williamson, O.E. 1975. Markets and Hierarchies. New York: Free Press.

Williamson, O.E. 1979. Transaction-Cost Economics: The Governance of Contractual Relations. Journal of Law and Economics, 22, 233 - 261.

Williamson, O.E. 1996. The Mechanisms of Governance. New York: Oxford U. Press.

Yin, R. K. 2009. Case Study Research: Design and Methods. USA: Sage Publications 
Kien Trung Nguyen : The Effect Of Institutional Context On The Governance ...

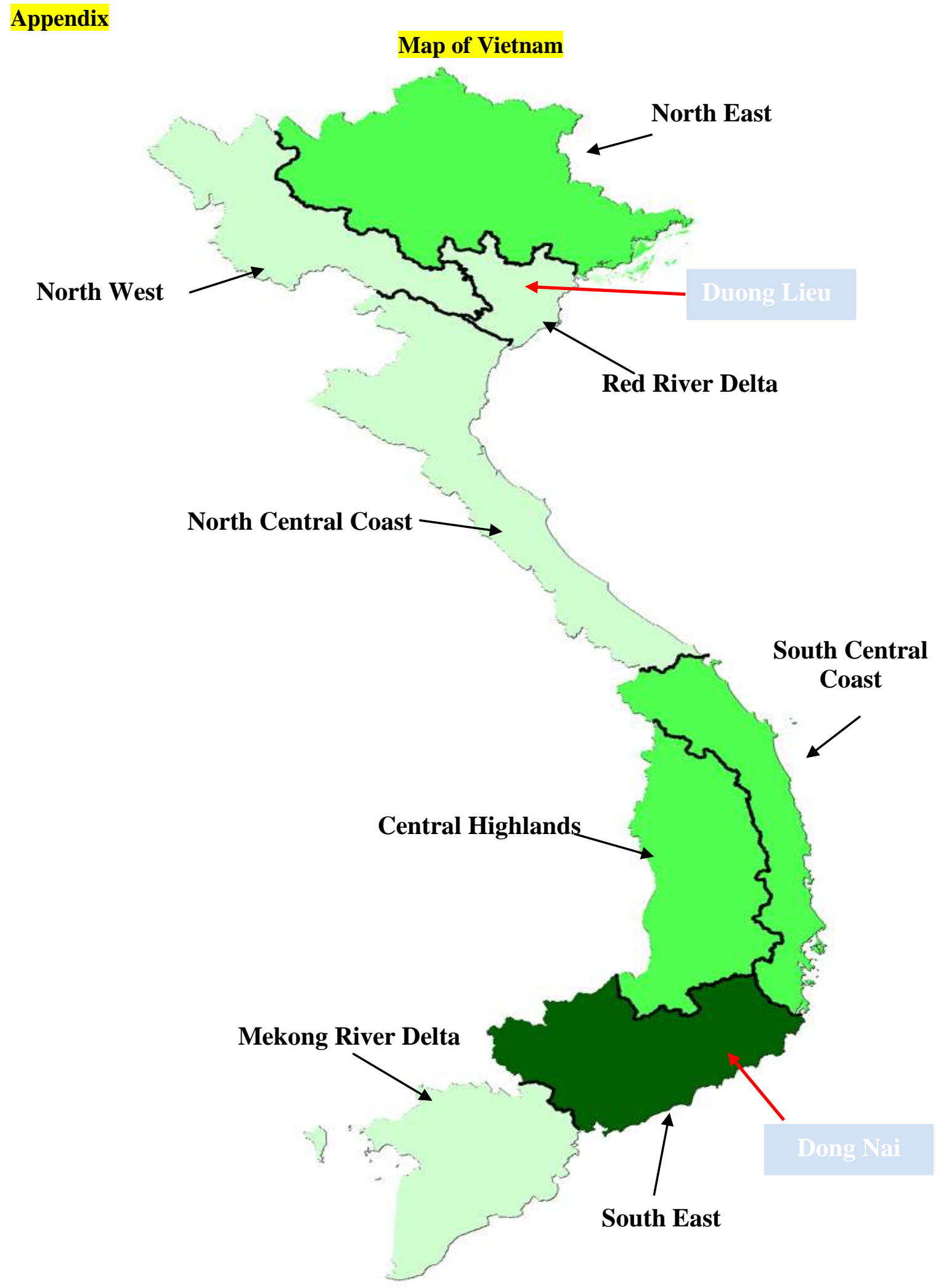

